\title{
Participatory water sources management model for schools: Case of Buhera district, Zimbabwe.
}

\author{
${ }^{1}$ Emmanuel Chinamasa, ${ }^{2}$ Freeman Mwaemudza Mavhiza \\ ${ }^{1}$ (Chinhoyi University of Technology) \\ ${ }^{2}$ (District Administrator, Buhera district)
}

\begin{abstract}
The purpose of this study was to find ways of sustaining water points in Buhera district schools. It was motivated by the observation that (40\%) of boreholes in the district broke down in 2010 and were not repaired. The situation forced school children to resort to unprotected water sources exposing themselves to water bone diseases. The study contributes to millennium development goal 2, (achieve universal primary education) and goal 7, (ensure environmental sustainability). The study was guided by a descriptive survey. Data was collected from a purposive sample of 198 (teachers, pupils, DDF and NGO officials in Buhera district) who .responded to a self reporting questionnaire. Observations of school children at water points, focus group discussions and analysis of DDF reports complemented the findings. The study revealed that, the main water source for schools and the community is the borehole. These are maintained by DDF. Water users role is confined to reporting borehole breakdown. They do not own the water sources that they use. The water points are overused promoting their rate of breakdown. There is no supervision of school children at water points contrary to literature recommendations. Use of plastic spare parts for metal casings contribute to borehole breakdown. The study recommends supervision and education of school children on the proper use of boreholes. The community and schools are encouraged to implement the suggested, "Participatory water sources management model" It promotes community ownership of the water point, its maintenance and sustainability. Skills transfer from experts to the locals is promoted in the process, there by developing the local skills base for water sources repair. Studies on the effectiveness of the model are encouraged.
\end{abstract}

Key Words: participatory study, models, water management, schools, boreholes

\section{Introduction}

Schools in communal settings like Buhera district in Manicaland province of Zimbabwe, share their water sources with the community in which they are located. As a result, the issue of strategies to sustain water sources is important not only for schools and this study but the survival of people in Buhera district which is wholly communal. It falls in the natural ecological regions three, four and five. The average temperature for the district annually is 34 degrees Celsius. Its average annual rainfall is $350 \mathrm{~mm}$. The bulk of the district, $80 \%$ lies in the ecological region four and five which receives an average rainfall less than $200 \mathrm{~mm}$ annually. As such, Buhera is a hot and dry district.

Rivers in Buhera dry up during the summer season leaving underground water as the only source of water. Such perennial water shortage calls for the need to avail more water sources in the district through construction of dams and drilling boreholes. In fact much of the water sources for schools in the district is confined to underground water. Each school has a borehole that may be functioning or not.

Water sources at Murambinda, Dorowa, Muzokomba, Buhera and Birchenough Bridge are administered by ZINWA. However it is only at Dorowa, Birchenough Bridge and Buhera where water challenges are not encountered in summer, all the other centres resort to borehole water when the rivers administered by ZINWA dry up. Save river is the water source for schools in both Dorowa and Birchenough Bridge. Nerutanga dam supplies water to schools in Buhera. To supplement water supplies, Buhera Rural district Council drilled five boreholes in October 2010 around Murambinda Growth Point in an attempt to curb perennial water challenges around the centre. Schools were prioritised in the drilling of boreholes in this area.

Morgan (2004) posits that the management of water resource should be a collectively shared burden by all stakeholders involved in water management. In Buhera forty percent of the boreholes have been drilled with the assistance of None Governmental Organisations (NGO). Major players in this field in the district of Buhera are Africare, World Vision, Mercy Corps, Zimbabwe Red Cross and Christian Care. On the other hand DDF account for fifty-eighty percent of the boreholes in the district. It is a requirement that, when an NGO drills a borehole it hands the borehole to DDF which is responsible for the management of all boreholes in the district.

Mubonani (2010) proposes that to sustain water sources there is also need to extend the management to the environment since vegetation has a direct impact on the water sources. This is critical for Buhera since the 
bulk $(80 \%)$ of its water is from underground. The situation calls for the proper management of the environment to ensure that water resource is conserved.

Management strategies for all water points must have a bias towards sustenance and prolonged life span of the water point. More so there is need to reduce strain at a water point so that its use is in line with the number of people it is supposed to serve. The Institute of Research in Rural Water and Sanitation (2008) recommends that for effective functioning of a borehole it should serve a population of two hundred and fifty while a well serves plus or minus fifty households. This implies that a population in excess of the stated number overuses and strains the borehole.

Zimbabwe Vulnerability Assessment Committee (ZIMVAC) report (2010) argues that there is need to improve water management strategies since a lot of resources were invested towards availing the water to the people. The success of any water management strategy rests on the involvement of the beneficiaries of the water point. Mtisi and Nicol (2005) concur with Morgan (2004) who advocates for stakeholder participation in water point management. Lovdal and Skjelfoss (2004) are supported by Africa Community Publishing and Development Trust (2008) which stresses that, recent trends the world over indicate that success in water source management is guaranteed when the level of stakeholder participation is high. Therefore it is imperative that stakeholders in Buhera are involved in their water projects from the initial stages to promote project co ownership. Chambers (2000) asserts that boosting people's sense of ownership translates to maximum care of the water points.

Mtisi and Nicol (2005) advocate for a decentralised management of water points since decentralisation promote collective action by communities. It also gives communities a measure of control over development activities that affect them. As such once communities are empowered to manage the water points they are in a position to supervise the functioning and operation of the water points.

The Rural District Council Act Chapter 29:17 went further to assert that it is the prerogative of the WADCO through its chairperson who is the councillor to meet the ward's water needs such as requests for additional water points, seeking assistance in maintenance and repairing existing ones.

\section{Statement of the Research problem}

Several boreholes drilled for schools in Buhera broke down and were not repaired. District Development Fund (DDF), November 2010 monthly report asserts that forty percent of the water points had broken-down. These breakdowns have resulted in the general members of the community particularly women and children being affected. They may be compelled to resorting to unprotected sources of water much to the danger of their health. Schools are also affected in their functioning since water is a health requirement for the operation of a school. Many children are grouped exposing them to water bone diseases. Community projects such as garden projects are also affected due to breakdowns of water points, hence community and school incomes are affected.

\section{Research Questions}

The study sought answers to the following questions:

1. What are the sources of water sources for Buhera schools?

2. What factors influence sustainability of water points in Buhera district?

3. What theoretical models of water point management can be used?

\section{Significance of the study}

This study sought to improve the maintenance of boreholes in Buhera district schools. Its findings can enlighten the population on sustainable strategies for management of water points. Buhera district Water and Sanitation Committee (WSC) benefits from water point management strategies suggested. Findings will also help the department of DDF to manage water points since it is the responsible authority for all water points in the district. The study also help the NGOs in their planning and implementation of water projects in the district since they are the ones providing the financial muscle to drill and rehabilitate water boreholes.

\section{Boreholes}

\section{Water Sources in Buhera}

Boreholes provide the safest source of water especially in rural areas. In the past the use of boreholes was a preserve of the rural folk. However the drilling of boreholes in urban areas and cities such as Harare and Bulawayo's communities being supplied with water from boreholes prove its utility value. Boreholes can be sunk manually, but are mostly drilled using specialised equipment to facilitate their ground penetration to deeper water levels. According to PACE (2008), water quality from a deep borehole is much safer due to filtration by several layers of soil. 
Participatory water sources management model for schools: Case of Buhera district, Zimbabwe.

Borehole drilling is conducted through water bearing layers to ensure a good abstraction. Morgan (2003) explains that boring rigs drill to at least forty metres before the borehole can be cased with PVC tubing. After drilling, a borehole is installed with some form of pumping system to extract water from underground. Of late the common type of pump used is the Bush pump type B, which is assumed to be user friendly.

\section{Deep Wells}

PACE (2008) points out that a deep well is dug where the water table is at a depth of twenty-five metres and less. The quality of water will depend on the depth of the water table, with deeper wells usually having a higher quality because of the deeper soil filtering processes. Never the less Morgan (2008) advised that should the wells not be protected they can easily become contaminated. If buckets or tins used to lift water are not clean they become sources of water contamination. Debris allowed to fall into the well adds to the contamination. Mitchell (1998) explained that, ideally wells should be sealed and water extracted using a pivot pump. Thus in some cases deep wells are fitted with pumps making it difficult to distinguish them from boreholes.

\section{Shallow Wells}

Shallow wells are also called catch pits. These are mainly shallow holes dug where the water table is relatively near the surface. PACE (2008) points out that these are often dug in the lower ends of river valleys. Mitchell (1998) advised that since shallow wells are open, they can easily be contaminated by runoffs and can also become a source of mosquito infestation. More so Cuny (2000) reiterates that the water is not completely filtered and therefore only suitable for watering, livestock and vegetable garden despite the fact that it is at times used for drinking in the homes. Drinking water from these sources can be a source of water borne diseases such as diarrhoea and cholera.

Donker (2006) further asserts that shallow wells usually dry fairly rapidly after the rain season. It is in light of this fore goings that shallow wells are mostly common and rife during the rainy season. It may also be the reason for the widespread of water related illness in rural areas during the rainy season since some people will be obtaining water from unprotected sources. Although Morgan (2003) asserts that the population that is in tandem with the shallow wells is fifty people no proper monitoring for these ratios is done in Buhera.

The total number of water points in the district according to the 2006 DDF record is 946 . Of these the bulk is constituted by boreholes (52.3\%) while deep well constitutes (22.6\%) and of these (25.1\%) are shallow wells. Naturally from the statistics it is clear that the major source of water in the district is the boreholes. Unfortunately the majority of them broke down and were not repaired, hence are in a dysfunctional state.

\section{Models of Water Point Management}

There are three major models of management of water points namely: Community Based Management (CBM), Public Sector Investment Project (PSIP) and Three Tier Model. They are described evaluated in the paragraphs below.

Community Based Management (CBM) came into being following the Earth Summit held in Rio de Janeiro in June 1992. According Mercy Corps (2009) the summit resolved that:

1. Water development and management should be based on participatory approach.

2. Decisions should be at lowest appropriate level with consultations and involvement of users in planning and implementation.

3. Support and assistance to communities in managing their own systems on sustainable basis should be provided.

4. Linkages between national, regional and district plans and community management within the context of overall planning must be developed.

Following the conclusion of the Earth Summit, the National Action Committee on Water and Sanitation in Zimbabwe, gathered with stakeholders in Nyanga in 1992 to adopt and organise the Zimbabwe Chapter of CBM. Mercy Corps (2009) reports that central to the discussion for the success of CBM were the need for: Organised local communities, active participation by women- since they constitute the bulk of water point users, accountability at local levels and private sector involvement. Unfortunately these resolutions ended in papers. They were not communicated to people in Buhera and are not yet implemented.

Chamber (2007) outlines the four principles of CBM as follows:

1. Communities are responsible for the development, operation and maintenance of their own primary water supplies.

2. Operation and maintenance cost must be met by community users. This is called the user pay principles.

3. Government and support agencies provide basic service at full cost for communal facilities. 
4. Government and support agencies hand over existing and future water points to the user community and their appropriate management structures.

Mercy Corps (2009) explained that each water point should have a committee of four composed of; the Chairperson, Secretary, Treasurer and Caretaker. The roles of the water point committee among others will be to work closely with local leaders and Village Pump mechanics in borehole repairing. The committee also ensures that water points' surrounding areas are clean. Its' other responsibility is to mobilise water point beneficiaries to perform any task required at the water point.

The water point committee is required to have a water point constitution which allows them to mobilise water point funds. It should keep records of pump breakdown and use. Mercy Corps (2009) reiterates that each and every record book is of importance to the Water point user committee and the community in general. The record books that should be available for every water point are: membership register, contribution register, constitution, water point general information, duty roaster, minute book, log book and tools' record/asset register.

In the implementation of the CBM Knowles and Materu (2001) points out that a concerted effort by various agents as needed. Among the agencies in Buhera are the Rural District Council, DDF, Environmental Management Agency (EMA), Local Government, Agritex and NGOs. Each agent is expected to play a unique role and avoid overstepping which will affect the smooth running of the program. The roles of each sector/ministry/agent are summarised as follows:

Table 1, Agent roles in Water Management

\begin{tabular}{|c|c|}
\hline AGENT & ROLES \\
\hline Rural District Council & $\begin{array}{l}\text {-management of water and sanitation projects at district level } \\
\text {-identification of developmental priorities with other sector agencies } \\
\text {-consolidation of district water supply plans } \\
\text {-monitoring performance of ward development structures }\end{array}$ \\
\hline DDF & $\begin{array}{l}\text {-rehabilitation of primary water supplies } \\
\text {-water point citing } \\
\text {-construction of deep well and head-works } \\
\text {-borehole drilling } \\
\text {-borehole human resource technical training } \\
\text {-updating of district water supply inventories }\end{array}$ \\
\hline Ministry of Health & $\begin{array}{l}\text {-health and hygiene education } \\
\text {-supervise construction of shallow wells } \\
\text {-water quality testing and monitoring } \\
\text {-supervise water points protection }\end{array}$ \\
\hline Ministry of Youth & $\begin{array}{l}\text {-community mobilisation } \\
\text {-community training in water source use } \\
\text {-monitoring of community inputs }\end{array}$ \\
\hline EMA & $\begin{array}{l}\text {-educate people on conservation awareness } \\
\text {-control the citing of gardens and cutting down of trees }\end{array}$ \\
\hline Local Government & $\begin{array}{l}\text {-water project co-ordination } \\
\text {-water programme monitoring and evaluation }\end{array}$ \\
\hline Agritex & $\begin{array}{l}\text {-advice on micro-agricultural projects related to water use } \\
\text {-land use planning }\end{array}$ \\
\hline NGOs & $\begin{array}{l}\text {-mobilise water resources } \\
\text {-control use of water funds } \\
\text {-water programme monitoring and evaluation } \\
\text {-community human resources trainings } \\
\text { - water projects trouble shooting }\end{array}$ \\
\hline
\end{tabular}

(Adapted from Mercy Corps (2009: 35) Training Manual for Water Point User Committee)

\section{Public Sector Investment Project (PSIP)}

The PSIP is a government funded programme extended to local authorities as a government grant. The programme entails Government channelling funds to Local Authorities who in turn allocate the funds as applied for from the Government.

The administration of the PSIP funds is based on district priorities as per needs and requirements of the district (Buhera Rural District Council- BRDC, 2007). For a water point to benefit from the PSIP funds, the community should have applied for assistance through notification of the Local Authority of its broken-down water point, when the funds are extended to the Local Authority they are then used in repairing the water point. This is mostly done through the ward councillor following a ward meeting to which developmental projects are discussed. When the funds are availed, the District water and Sanitation Committee sits, discuss and agree on which water points to benefit from the available list. Prioritisation is critical because the amount extended will not be enough for all the water points in need of repair/rehabilitation. It is safe to conclude that, such scarce funds are awarded to politically influential councillors. 
In as much as the programme is wholly government funded the disbursement of funds is not time conscious and sensitive to the needs of the communities. As a result some communities end up having their boreholes unrepaired for long periods. In such circumstances, people resort to unsafe water and or congesting at nearby functioning water points. The congestion strains the pump and reduces its' life span.

Once the funds are released Local Authority through the department of DDF will rehabilitate the broken down water points. PSIP does not allow for community contribution. Locals are only required to report the water point breakdown. Mercy Corps (2009) observes that by non-participation communities are at times bound to misuse the water point which they do not regard as theirs. From this point they advocate for community participation to ensure that a sense of responsibility and accountability is inculcated among the water point users.

\section{Three Tier Model}

The three tier model was initiated by DDF sometime ago. It operates at three levels namely; the village, ward and district level hence the name three tier. Member roles at each level are examined below:

\section{Village Level}

DDF Manual (1997) points out that a committee is formed by families who actually use the hand pump. The committee is called a Water Point Committee. It is responsible for assisting DDF pump minders with the maintenance and repair of the water pump.

The committee ensures that the hand pump is properly used through control of how it is used and should any faulty be detected, it is reported to DDF community workers who in turn comes and repair the water pump. The DDF community workers are known as pump minders and they operate at ward level. At village level the roles of the committee is not so visible and have its own limitations in that it does not take into account community input.

\section{Ward Level}

This is the second level where the pump minders are visible. The pump minders are jointly selected by the community, councillors and DDF officials. DDF Manual (1997) points out that the pump minders will be trained by DDF to carry out maintenance and repair of all the water pumps in the ward. In theory each ward will have its own pump minders to cater for the ward's water pumps. These pump minders are employed as casual employees of DDF and are paid a monthly allowance for the work that they do. Implied in this set up is the fact that, if there is no pump repaired, then the pump minder has no income that month. The DDF Manual (1997) points out that the pump minders are equipped with a tool box and tools for use. However the tools remain a property of DDF.

DDF Operations Manual (2001) sets the duties of pump minders to include minor and to some extent major maintenance such as:

1. Visiting all water points in the ward to check on their conditions and carry out maintenance and repair.

2. Report the state of water points to DDF monthly.

3. Report major problems to the department of DDF responsible for water supply operatives.

\section{District Level}

DDF Operations Manual (2001) points out that DDF Water Supply Officers have overall responsibilities for DDF water activities in the district. The field officer will be responsible for maintaining records of all pumps in the district and update it using pump minders' reports.

Wells and Hand pumps Manual (2005) sets the duties of the water officer as:

1. Supervising the pump minders.

2. Issue spare parts to pump minders and keep record of issued parts.

3. Assist pump minders with major repairs.

4. Collect monthly reports from pump minders.

5. Assist pump minders to fit new pumps.

From the afore goings on the three tier, it is clear that the overall control of water points lies with DDF with little from the direct beneficiaries from the communities. According to the model all problems are reported to the pump minders who are DDF operatives (employees) who in turn repair or rehabilitate the water points. The role of community members is limited to reporting faults to DDF and to a lesser extent assisting the pump minders when they do the repairing of their water points yet they should be in the fore front. Since pump minders are casual workers, they leave the community for employment in towns after training.

Due to economic challenges, this model is no longer viable as was the case in the past. The major challenges faced by DDF as postulated by Munemo (2010) are logistical challenges which among others include lack of transport, lack of spare parts and no funds available to pay pump minders who used to be DDF's casual 
employees and were paid some monthly allowances. Such a scenario make implementation of the model virtual impossible, hence its dissolution. As a result, for DDF to assist the needy communities, the communities have to contribute fuel and food for the DDF personnel to come into their communities and repair the water points. This is a challenge when communities have no funds for the pump maintenance.

\section{Research Design}

\section{Research Methodology}

This study exploring sustainable management of water points by communities in Buhera district used a descriptive survey case study design. A case study was adopted in order to facilitate a deeper understanding of the phenomena using a relatively small sample (Babbie, 2001). The study is a case of Buhera (location) and water source management (single phenomenon). Limiting the study to a specified location, phenomenon and sample facilitates a deeper analysis of findings. On the other hand a descriptive survey case study was adopted for allowing the use of multiple instruments in data collection. Instrument triangulation facilitates validity and reliability of study findings.

In the same vein Polit and Hungler (2002) state that qualitative descriptive research design is a scheme of action for answering the research question(s) based on a confined area. A case study is an extensive examination of a single instance of a situation of interest (Chawawa, 2002). It focuses on understanding the dynamics of variables within Buhera which influence management of water sources.

Leedy (2000) points out that descriptive survey entails describing what is seen. This calls for the use of observations of people using water points. Observations help to answer the, who uses them? and how they are used? Saslow (1998) further points out that there is need for a detailed description of data collection methods and findings. The descriptive survey research is also designed to describe phenomena/variables or to find relationships between variables (Gall, Borg and Gall, 2001). In this case the relationship between water point breakdown and management strategies will be described. Further to that it also establishes practices prevailing. Specifically the study captures existing management strategies and practices at water points.

Cohen and Manion (2003) further point out that the purpose of descriptive survey is to get the general view of water point users on sustainable management of water points. In the process it allows the collection of original data for purposes of describing water point users. In the same vein Van Dalen (2006) reiterates that descriptive surveys are vehicles for measurement of orientations prevalent in a large population.

\section{Population}

The human population of this study is comprised of school teachers, pupils and DDF officials in Buhera. The second set of population is made up of water points, DDF water reports and minutes of district development meetings. These are within the communities who get water from water points, Governments departments into water related activities and Non-Governmental Organisation implementing the Water and Sanitation program in the district. Water point users in ward four and sixteen are different as such there are certain characteristics which are peculiar to the ward. By the same vein, NGOs and Government departments are different hence they are considered as different clusters.

Non-governmental Organisations all Program Managers and Project Officers and support staff comprised the population. The population with respect to Government Departments is comprised of all Ministries engaged directly in water related activities. The ministry whose population participated in this study: Ministry of Education, Ministry of Health, Buhera Rural District Council, Ministry of Local Government, Ministry of Youth and Ministry of Women Affairs,

\section{Sampling}

Since the population is divided into clusters, the study used cluster sampling for wards in the district. According to Gwimbi and Dirwai, (2003) a representative sample can be raised by simple random sampling. Since water use per water is expected to be the same, simple random sampling for water points to be visited was applied. Bryman and Bell (2007) advise researchers to use purposive sampling when the population is small. In this study, representatives of different organisations are few. Purposive sampling was applied. Participants were selected on their being available, willing to participate and having knowledge of water point management. Qualitative research allows for the inclusion of new rich sources of the variable as they arise rendering the sample frame flexible (Bordens and Abbott, 2002).

\section{Data Collection Methods}

Understanding is a cognitive phenomenon which can be established by use of several data collection instruments. According to Chisaka (2001) the researcher is the key instrument for data collection in qualitative research. Data collection was initiated by seeking permission from the District Authorities namely the District Administrator and Chief Executive Officer for BRDC. The researchers introduced themselves to community 
leadership. Instruments for use were designed by the researchers. They were pilot tested on water point users in ward five as part of its construct validation process. Preliminary visits were also made to the wards for familiarisation.

\section{Surveys}

Researchers structured and used self reporting questionnaires for literate community participants as the main research instrument. Researchers distributed and collected questionnaires from participants. The questionnaire enabled individual views from a large population to be captured within a short period of time. Respondents recorded their views, hence original data was captured. Respondent were also able to respond without fear of having their identities revealed. The main questions on the questionnaires sought demographic data and management strategies of water points.

NGOs and Ministry officials responded to open and close ended questions. Open ended questions enabled respondents to express themselves beyond the confines of the researcher. They explained how they operate and where able to clarify constrains. Whereas the close ended questions stood to guide the respondent within the dictates of the researchers thereby enabling researchers to have varied responses.

\section{Focus Group Discussion}

Focus group discussions were used to solicit data from participants from different water points. These were mainly parents who collected water from the same water point. This enabled the study to capture collective agreeable responses following some discussions. One purpose of focus group discussion is to collect group views. Participants carried out some discussion in groups before the various groups gathered to form one cluster. The groups then did some group report back presentations. As a single group some discussion were carried out before coming up with one agreed response which became the focus group's position.

\section{Interviews}

Face to face interviews were also used to solicit information from heads of Government Departments/Ministry in the district. These interviews were conducted to get a deeper understanding of the department or ministry's roles and responsibilities on sustainable management strategies of water points. In addition, interviews sought officials' of water management strategies. Tuckman (2001) considers interviewing as directed conversation which permits an in-depth exploration of a particular topic. It was very critical in sustainable water point management in soliciting for participants' understanding.

Gall, Borg and Gall (2001) recommended interviews for facilitating the interpretation of nonverbal cues. It provided opportunities for validating participants' understanding by probes for example clarification and rephrasing of statements and comments. Interviews enabled researchers to ask follow up questions and or rephrase the question where the researcher felt that the participant was failing to comprehend the question. In the process accurate information was solicited and extracted from the participants.

\section{Observations}

Researchers visited 10 selected water points and spent the whole day, from $6.00 \mathrm{am}$ to $7.00 \mathrm{pm}$ at each water point observing the use of water point. Researchers noted the uses, how school children operate the pumps and the nature of supervision if it was provided. Pupils' actions as they use water pumps are detrimental to the frequency of breakdowns. Elders in the community were also observed on the way they use the water point to see if their actions have positive or negative impact to the water point. Notes were done during the process.

\section{Documentary Analysis}

Analysis of records kept at the department of DDF and Buhera Rural District Council was carried out to determine the nature of complains forwarded and the rate at which reports are forwarded to the organisations. Minutes from DDF identified resolutions to issues pertaining water points breakdown and repair in the district. Documents were readily available and accessible to the researchers. Information sourced from documentary evidence is seen as free of bias and can be recollected for verification if necessary (Best and James, 2000)

\section{Data Analysis}

Questionnaires were screened for completeness and answering of key questions. Responses were then coded against themes from research questions, namely: users, frequency of borehole break down, repairs and management strategies. Data from reports and observation notes points and recording them according to research questions. Focus Group Discussions were analysed by transcribing group presentations then discussion content for common understanding and points of variations. The aim was to establish trends and patterns of conceptions that appear within a single focus group or were common among the groups. Consistency on the participants' comments and specific responses to follow up probes were also considered. 


\section{Findings and Discussions}

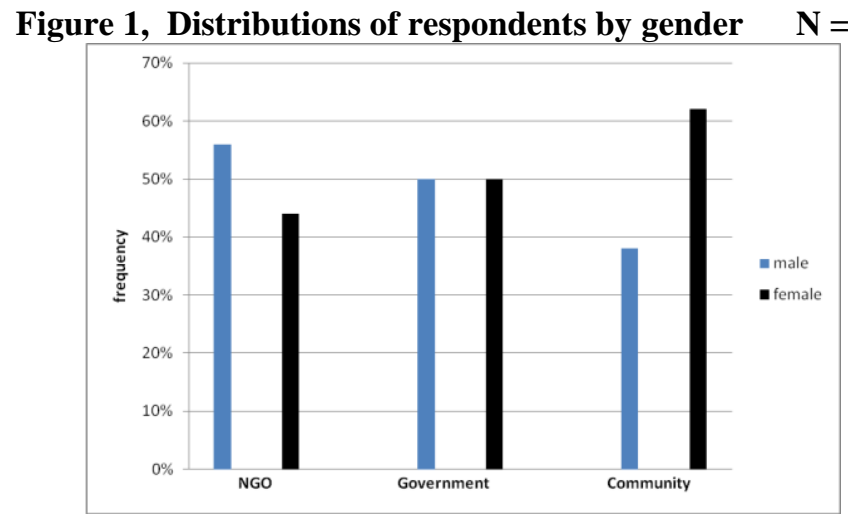

Figure 1, shows that $(62 \%)$ of community participants were female. These form the majority of water point users hence their responses can be relied upon. The majority of respondents from NGOs are males. This can be accounted for by the fact that, the majority of NGOs employ males.

Table 2, Distribution of participants by ages $\quad \mathrm{N}=198$

\begin{tabular}{|l|l|l|l|l|l|}
\hline \multirow{2}{*}{ Age (years) } & Number of respondents from: & \multirow{2}{*}{ Total participants } & $\begin{array}{l}\text { Percent of total } \\
\text { participants }\end{array}$ \\
\cline { 2 - 5 } & NGO & Government & Community & & $9.1 \%$ \\
\hline Less than 20 & - & - & 18 & 52 & $35.4 \%$ \\
\hline $21-30$ & 10 & 8 & 52 & 52 & $26.2 \%$ \\
\hline $31-40$ & 5 & 7 & 40 & 58 & $29.3 \%$ \\
\hline $41+$ & 3 & 5 & 50 & $\mathbf{1 9 8}$ & $\mathbf{1 0 0 \%}$ \\
\hline Totals & $\mathbf{1 8}$ & $\mathbf{2 0}$ & $\mathbf{1 6 0}$ & \\
\hline
\end{tabular}

Table 2, shows that $(9.1 \%)$ of the total participants were school children from community participants below 20 years. The highest percent was contributed by the age group 21 to 30 years which had (35.4\%) of the participants who constitute the bulk of active water point users in rural areas. The majority (91\%) are above 21 years. They are mature enough to suggest sustainable strategies for managing water points in their communities.

Table 3, Distribution of water points by type $\mathrm{N}=946$

\begin{tabular}{|l|l|l|l|l|}
\hline Type of water point & $\mathbf{N}^{\mathbf{0}}$ of water points & Percent & Recommended population & Actual population \\
\hline Shallow well & 237 & 25 & 11850 & 15372 \\
\hline Deep well & 214 & 23 & 32100 & 39671 \\
\hline Borehole & 495 & 52 & 123750 & 149599 \\
\hline Total & $\mathbf{9 4 6}$ & $\mathbf{1 0 0}$ & $\mathbf{1 6 7 7 0 0}$ & $\mathbf{2 0 4 6 4 2}$ \\
\hline
\end{tabular}

Findings revealed that boreholes constitute the highest percent of water points accounting for $(52 \%)$ of the water supply points. Findings from the study revealed that the distribution of water points in the district is not commensurate with the district's total population. Morgan (2004) states that a deep well serves a population of 150, while a shallow well serves a total population of 50 and a borehole serves a population of 250 . According to these standards, water points in Buhera are overused. Researchers noted that community members got water for building projects from the same boreholes. School children were not supervised in any way when they used water points. These factors contributed to the high rate of borehole breakdown.

Report analysis revealed that $(56 \%)$ of the water points are functioning while $(44 \%)$ are not functioning. From the findings on the state of water points it may mean that a significant population (44\%) is faced with the challenge of water since their water points are not functioning. The percent of non-functioning water points is in line with DDF's November (2010) monthly report in which forty percent of water points were reported as not functioning. It may be argued that the prevailing scenario where (44\%) of water points are not functioning results in queuing at the functioning water points. More so it is when people queue that may also result in over use of some water points which may lead to breakdowns. More so observations showed that it is when people queue for water that there is careless pumping, poor handling and general care of the water point that may result in increased chances of breakdowns. However notable long queues were observed to happen early in the morning and in the evenings. It may be caused by the increased demand for water during the periods. More so the queuing for water also contributes to extended use of water points and general overuse. 


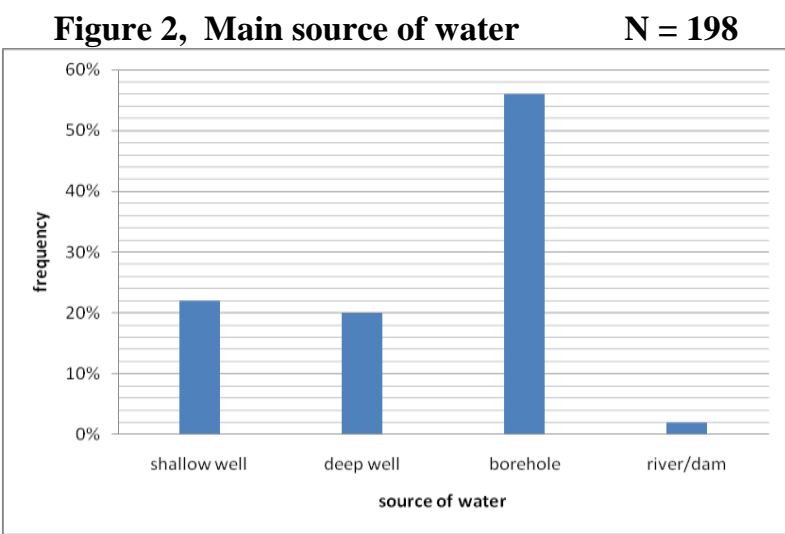

Participants revealed that $(56 \%)$ of them obtained water from boreholes, whereas $(2 \%)$ indicated that they sourced water from rivers/dams. The findings from the study revealed that a small percent source water from unprotected source that is rivers/dams which may be an indication of the widespread of the practice among the community. The sourcing of water from unprotected water points may be a result of the limited availability of surface water. Cuny (2000) reiterates that water from unprotected sources is not suitable for human health as it may be a source of illness. As such it may be necessary to discourage people from obtaining water from these sources; however they may not have better alternatives.

Fetching water from rivers and dams may be caused by sparsely placed water points which forces people to source water from unprotected sources or their water points are on breakdown. Resorting to river/dam water may be as a result of long distances to safe water points that people opt for water from unprotected sources which may be nearer. Such revelations may be an indication of deficit of water points.

Figure 3, Source of spare parts for repair

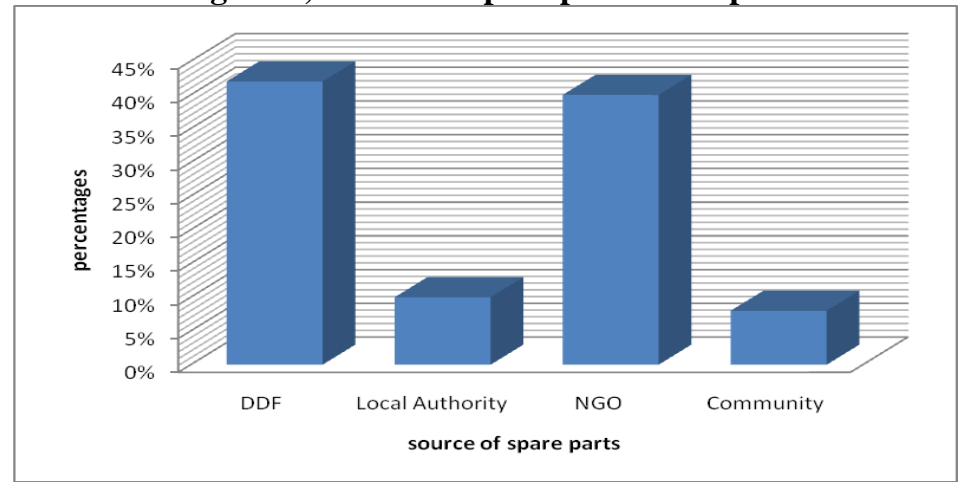

The study revealed that DDF is accounting for (42\%) and NGOs accounting for (40\%) of the major players in the provision of spare parts for the repair of water points. The most common spare parts purchased were found to be wooden block, leather cup, valve cage and rod lock nuts. Local Authority in this case Buhera Rural District Council is playing a minimal role as it is not so visible on the ground since it only accounted for $(10 \%)$ of the respondents. The community is neither doing much as well since it was $(8 \%)$ who acknowledged that communities were providing spare parts for their water points. Mercy Corps (2009) argues that the concept of CBM hinges on communities forming management structures and collectively taking responsibility in resourcing and management of their water points. As such by accounting for only (8\%) it may be argued that the desired goal of CBM has not been achieved in Buhera. However the DDF water and Sanitation Grant is evidently visible since it was acknowledged by (42\%) as providing spares for water points.

Table 4, Factors contributing to water point breakdown

\begin{tabular}{|l|l|l|l|}
\hline \multirow{2}{*}{ Factors } & Responses from: & Gommunity \\
\cline { 2 - 4 } & NGO & $5 \%$ & $21 \%$ \\
\hline Misuse and poor handling & $15 \%$ & $9 \%$ & $3 \%$ \\
\hline Negligence & $10 \%$ & $7 \%$ & $3 \%$ \\
\hline Poor management & $8 \%$ & $13 \%$ & $3 \%$ \\
\hline Lack of ownership & $12 \%$ & $32 \%$ & $35 \%$ \\
\hline Overuse & $40 \%$ & $7 \%$ & $13 \%$ \\
\hline Lack of maintenance & $10 \%$ & $20 \%$ & $17 \%$ \\
\hline Poor equipment & $5 \%$ & $7 \%$ & $5 \%$ \\
\hline Theft and vandalism & - & $\mathbf{1 0 0}$ & $\mathbf{1 0 0}$ \\
\hline Total & $\mathbf{1 0 0}$ & \\
\hline
\end{tabular}


From the research findings, it is evident that overuse of water points is the major factor influencing water point breakdown. Community (35\%), Government departments (32\%) and NGOs (40\%) all agreed that there is a general overuse of water points in the district

NGOs (10\%), Government (7\%) and community (13\%) reported that lack of maintenance was also a factor contributing to water point breakdown. The trio agreed that lack of maintenance of water points was widespread. To prolong the lifespan of a water point there is need for maintaining it. Findings revealed that users may not be maintaining their water points leading to their accelerated breakdown. Morgan (2000) argues that minor operations should be left to WPU who are in daily conduct with the water point. Thus operations like greasing and lubricating the parts of a water point can be done easily by WPU, in the process sustaining the water point. However it was observed that WPU do not take it upon them to ensure that borehole is lubricated. It was observed by the researchers that people were continuously pumping a borehole which was evidently in need of grease. Despite the wear and tear noise users were observed pumping as if there was nothing amiss.

Lack of ownership was indicated as a factor by NGOs (12\%) and Government departments (13\%).. There is need to inculcate a sense of ownership among WPU for them to be responsible in the use of their water points. Chambers (2007) advocate for a decentralised decision making process to enhance ownership through participation. Moreover should people have a sense of ownership, Morgan (2000) highlights that they will be in a position to physically check the parts of a borehole and ensure that all who use it do so responsibly. In a visit to a water point ownership was perceived as lacking as no one was bothered to stop children who were observed swinging on the borehole despite the presence of adults. Children were also observed playing on the borehole ramming its handle against the ground whilst others were observed swinging on the handle.

Findings revealed a difference on NGOs (5\%) and Government departments (20\%) and community (17\%) perceptions on the use of poor quality equipment. Government departments and community participants agreed that some poor spare parts were contributing to water point breakdown. However NGOs seem not to agree we thought they were defending the quality of equipment that they provided.

Never the less it may be pointed out that the spare parts fitted may lack compatibility on a borehole. The equipment used during the initial construction of the borehole was from Britain. Repairs are now being done with spare parts from China. More so the material of the parts may be made from different materials, with plastics being used to replace metal cases.

Community $(5 \%)$ and Government departments $(7 \%)$ pointed out that theft and vandalism was a contributing factor to water point breakdowns. Pipes, handles and rods were prime parts stolen. Pipes are sold to farmers who in turn use them as irrigating pipes in their farms; schools also use them as goal posts in their grounds. Rods are used by blacksmith in the manufacture of stoves. However some parts are stolen and fitted in other water points.

\section{Study Recommendations}

On the basis of these findings, this study recommends these:

\section{District level}

1. The district authorities (District Administrator, CEO of BRDC, DDF and district Water and Sanitation Committee) need to come up with a standardised Community Based Management training manual so that any training carried out will be meeting the district's specifications. Unlike what is happening where each organisation has its own training manual.

2. There is also need to drill more water points so that they are commensurate with the population of the district. At the present moment the numbers of water points are not in tandem to the population, as such demand stretches beyond the water points' limit.

3. There is need to replace old equipment at water points with durable spare parts which lasts, unlike cases where spare parts of poor quality are used which would not last.

4. At district level, DDF as the water point authority should be financed by Government so that it is in a position to travel, monitor and evaluate state of all water points.

5. The district needs funding from partners or from Government to enable it to update its water data base so that there is an official record of all the existing tools and water points.

\section{Community level}

1. At community level there is need to train pump minders and certificate them so that they could do the repairing of water points at community level.

2. At community level there is need for increased sustainable management of water points by communities through engaging in income generating activities so that funds generated will be used to manage the water point's repair, maintenance and management. 
Participatory water sources management model for schools: Case of Buhera district, Zimbabwe.

\section{Policy formulation}

1. A policy should be instituted by district authorities at community level for proper hand over and take over between the community and NGOs. This will instil a sense of ownership in the community in the sense that a water point would have been handed to the community for management.

2. A policy should be put in place by district authorities that make it mandatory to drill water point in winter when the water table is low so that the availability of water will not be affected in winter when water tables are low. More over the existing water points where water dries in winter to be deepened in winter.

3. There is also need to harmonise the water provision operations by government departments and NGOs since they seek to attain the same goals. Tendencies of competing against each at the expense of service delivery should be discouraged.

\section{Recommended Participatory Management model}

A water point management model named Participatory sustainable water point management model is recommended for implementation. It has four developmental stages as presented below:

Stage 1 Agent (internal or external) together with Community members

-sensitise locals on water challenges

-Discussion of possible solutions to the water challenges

-Selection of appropriate solution

Stage 2 Resource mobilisation by locals

-Formation of water management committee

-Mobilisation of financial, human and material resources

-Application for donations

-Management strategies formation by locals with advice from agent

- Setting up a fund

Stage 3 -Installation of water point

-Local human resource training

-Locals installing under expertise supervision of Agent

-Awareness campaigns on use of water point

Stage 4 -Water point management and supervision

-Locals implement water point management strategy (repairs, lubricating constitutions)

-Agent role withdrawn to zero

Figure 5, Graphical comparison of Agent and local participant contributions in model

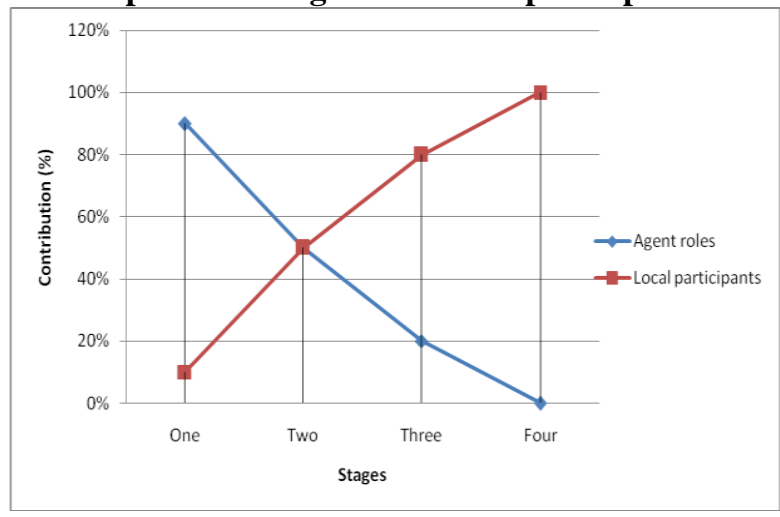

References

[1]. African Community Publishing and Development Trust (2008), Sowing our seeds: strengthening citizen participation in local decision making. Cape Town: Fingerprint Co-operative Ltd.

[2]. African Community Publishing and Development Trust (2009), Rising Again: Community Views on Local Control over Local Resources. Cape Town. Fingerprint Co-operative Ltd.

[3]. Babbie, E.R. (2001), The Practice of Social Research (12 ${ }^{\text {th }}$ Edition). Belmont: Wadsworth

[4]. Best, J.W. and James, K.V. (2000) Research in Education ( $8^{\text {th }}$ Edition). Boston: Allyn\& Bacon.

[5]. Bordens, K.S. and Abbott, B.B. (2002), Research Design and Methods: A Process Approach (5 ${ }^{\text {th }}$ Edition) Boston: McGraw Hill.

[6]. Bryman, A. and Bell, E. (2007), Business Research Methods ( ${ }^{\text {rd }}$ Edition) New York: Oxford University Press.

[7]. Canhao, M. T. and Keogh, E. (2004), Research Methods. Harare: University of Zimbabwe.

[8]. Chambers, R. (2000), Revolution in Development Inquiry. (s.l) University of Sussex.

[9]. Chambers, R. (2007), Revolution in Development Inquiry. (s.1) University of Sussex.

[10]. Chawawa, M. (2002), Research Methods and Statistics. Harare: University of Zimbabwe. 
[11]. Chenje, M. and Johnson, R. (Ed) (1999), State of the Environment in Southern Africa. Johannesburg: SADC ILRN.

[12]. Cohen, L. And Manion, L. (2003), Research Methods in Education. Beckenham: Croom Helm.

[13]. Cooper, D.R. and Schindler, P.S. (2008), Business Research Methods $\left(10^{\text {th }}\right.$ Ed) New Delhi: Tata McGraw Hill.

[14]. Cuny, B. (2000), Living with Floods: Alternatives for Riverine Flood Mitigation. (s.l) (s.n)

[15]. Donker, S.M. (2006), Water in Africa Management Options to Enhance Survival and Growth; European Commission for African. NEPAD Support Unit. (s.l) (s.n)

[16]. Gall, M.D.; Borg, W.R. and Gall, J.P. (2001), Educational Research: An Introduction ( $8^{\text {th }}$ Edition) New York: Longman Publishers.

[17]. Gwimbi, P. and Dirwai, C. (2003), Research Methods in Geography and Environmental Studies. Harare: Zimbabwe Open University.

[18]. Knowles, E. and Materu, J. (2001), Partnerships for Sustainable Development: North-South Cooperation within the Framework of Local Agenda 21 Africa. Lancaster: Carnegie.

[19]. Leedy, P.D. (2000), Practical Research: Planning and Design. ( $5^{\text {th }}$ Edition) New York: Macmillan Publishing Company.

[20]. Linger, H. (2000), Endangered Water: A Global Overview of Degradation Conflicts and Strategies for Improvement. (s.l) University of Berne.

[21]. Lovdal, I. and Skjelfoss, E. (2003), Water Engineering Design (vol.8.1) Ministry of Water Resources. National Master Plan for Water Supply and Sanitation. Harare: (s.n)

[22]. Lovdal, I. and Skjelfoss, E. (2004), Water Engineering Design (vol.8.1) Ministry of Water Resources. National Master Plan for Water Supply and Sanitation. Harare: (s.n)

[23]. Mercy Corps (2009), Training Manual for Water Point User Committee (s.l) (s.n)

[24]. Mitchell, B. (1998), Integrated Water Management: International Experiences and Perspectives. London: Belhaven Press.

[25]. Morgan, P. (2000), Blair Research Bulletins for Rural Water Supply and Sanitation. Harare: Institute of Research.

[26]. Morgan,P.(2004) Rural Water Supplies and Sanitation: A Text from Zimbabwe's Blair Research Laboratory. London: Macmillan Education Ltd.

[27]. Mukwada, G. (2000), Natural Resource Conservation and Management. Harare: Zimbabwe Open University.

[28]. Mtisi, S. and Nicol, A. (2003), Sustainable Livelihoods in Southern Africa: Institutions Governance and Policy Process. (s.l) (s.n)

[29]. Mtisi, S. and Nicol, A. (2005) Sustainable Livelihoods in Southern Africa: Institutions Governance and Policy Process. (s.l) (s.n)

[30]. Oartridge, J.W. (1998), Why is Freshwater an Issue for Business: Environment and Corporate Controls. UN Department of Economic and Social Affairs. (s.l) (s.n)

[31]. Polit, D.F. and Hungler, B.P. (2002),Nursing Research Principles and Methods. New York: Lippincott Publishers.

[32]. Saslow, C.A. (1998), Basic Research Methods. New York: McGraw Hill.

[33]. Tuckman, B.W. (2001), Conducting Educational Research (4 ${ }^{\text {th }}$ Ed) San Diego: Macmillan

[34]. Van Dalen, D.B. (2006), Understanding Educational Research: An Introduction. New York: McGraw-Hill.

\section{Journals/Reports}

[35]. Chisaka, B.C. (2001), A Qualitative Analysis of Perception of Learners in High Ability Classes in Zimbabwe. The Zimbabwe Bulletin of Teacher Education. 1.(3) Pgs 33-49

[36]. Chief Executive Officer Buhera Rural District Council (2009), Full Council Minutes September 30.

[37]. DDF Manual (1997) Operations and Procedures. UNICEF (s.l) (s.n)

[38]. DDF Operations Manual (2001) Manual for Water Field Officers. Harare: (s.n)

[39]. Institute of Research in Rural Water and Sanitation (2008) Water and Demand SupplManagement for SARDC in Southern African Environment. Issue No 7. CEP Water Fact Sheet.

[40]. Mubonani, R.L. (2010) Managing the Environment Sustainably. Paper presented at a conference on Strategies for Management of the Environment. Wise- Owl. Mutare, April.

[41]. Munemo, T.N. (2010) DDF Buhera monthly report for November

[42]. National Population Census (2002) Harare: Government of Zimbabwe

[43]. Participatory Agricultural Curriculum for the Environment (2008) Sustainable Water Management. Brussels: VVOB.

[44]. Zimbabwe Vulnerability Assessment Committee (2010) ZIMVAC 2010 Report. Harare: Government of Zimbabwe. 